\title{
Futures of area-based initiatives in German education: results from a quantitative Delphi survey
}

\author{
Anika Duveneck*, Julius Grund, Gerhard de Haan and Kathrin Wahler
}

\begin{abstract}
To support schools, improve learning outcomes, create innovative learning opportunities, and reduce social disadvantage, many countries have introduced policies to mandate or incentivize educational networks in the last decade. This study focuses on Germany, where around $80 \%$ of municipalities established area-based initiative (ABI) structures following a broad range of ABls. However, research has revealed a gap between intentions and implementation: There is a strong bias toward governance structures, while educational aims have not been achieved. To provide a foundation for purposeful development, a Delphi study has been conducted. Based on a sample of 180 nationwide $\mathrm{ABI}$ experts, data was collected in two steps using an online questionnaire on preferred and probable developments in crucial ABI fields. Statistical analyses offer insights into the relation between desirability and expectation and the degree of consensus or divergence among experts. The study shows that after 10 years of experience, the discrepancy between intentions and implementation is expected to remain. Further, it reveals tendencies on the level of governance and thereby contributes to identifying the scope of ABls. The study concludes that, for future development, it is necessary to define ABIs' contributions to their initial aims and to reassess their legitimacy.
\end{abstract}

Keywords: Area-based education, Educational networks, Educational governance, Delphi method, Rationalized myth

\section{Introduction}

When it comes to the future of educational systems and structures, there is a broad consensus that the "inspiring future for education" is collaboration [1]. In a world of fast-paced change, increasing complexity and therefore a high degree of uncertainty, there is a constant need to adapt, learn, grow, and collaborate ([2]; see also [3, 4]). Schools can no longer cope with these challenges alone. There is no doubt that, as the OECD [5] argues, educational institutions must learn within networks. In the last decade, many European countries have therefore introduced policy reforms establishing area-based initiatives (ABIs) in education to foster cooperation among educational actors such as teachers as well as multi-professional cooperation and multi-agency cooperation with actors from administration, civil society, etc. [2, 6].

\footnotetext{
*Correspondence: Duveneck@institutfutur.de

Freie Universität Berlin, Berlin, Germany
}

This study focuses on the future development of ABIs in the German education system. This system is particularly instructive due to its uncommonly high degree of social selectivity, as the PISA study revealed at the turn of the millennium [7]. On the one hand, this selectivity results from the three-tier school system, which divides students into lower-, middle-, and higher-level secondary schools. On the other, it goes back to the focus on formal education [8] rooted in the nineteenth century German notion of family. Accordingly, the state was supposed to provide education, while childcare was regarded as a matter for families (or to be more precise, for mothers). As state intervention was only regarded as legitimate in case of need, childcare and youth work became part of youth aid welfare systems on a local scale. In the formal school system, local municipalities are only responsible for school infrastructure (buildings, janitors, etc.), while federated states are responsible for content. 
Accordingly, in their administration, formal education and non-formal education on the local scale are separate systems. Area-based initiatives in Germany aim to create an interface between the two in order to encourage cooperation, to expand education beyond schools and thus to challenge the foundations of social selectivity beyond the scope of federated states.

The starting point of ABIs in German education can be found in 2007 with a debate characterized by high expectations on a broad range of goals, from improving learning outcomes, creating more attractive and needsoriented learning opportunities, enhancing cities' and regions' attractiveness and-most important-reducing social disadvantage ([9]: 300; see also [10]: 8; [11]: 227 [12]). Stakeholders from schools, non-formal education, city, regional, and federal governments as well as foundations established various ABI programs (see [9]: 22; [13]: 18), among them "Learning Locally" from the Federal Ministry of Education and Research [14]. Since 2014, nationwide transfer agencies have supported cities and regions in developing structures of local educational management for area-based education. These agencies transfer best practices from model projects to cities and regions all over the country. Brüggemann and Tegge [15] found that $80 \%$ of German districts are formally involved in ABI programs, hold objective agreements on local educational management or do local educational reports. Programs with a focus on educational aspects ended or became part of the transfer agencies. Still, even after a decade of experiences, there is no shared understanding of how ABIs can be defined ([16]: 235; [17]: 90; $[18,19])$. This raises the questions: What exactly is going to be transferred? What do we know about ABI implementation?

\section{Monitoring and evaluations}

There is very little evidence on the impact of ABIs in education for Europe as a whole. However, some studies have evaluated educational ABI programs using elaborate methods, and outcomes for social advantage are poor [6]. In France, ABIs are called "Zones d'Education Prioritaires." Due to their long tradition, they have been studied through multiple iterations and designations. Still, "there is little evidence that they have had a significant impact in reducing the effects of disadvantage on children's educational outcomes" ([6]: 6; see [20, 21]).

In England, ABIs became crucial in educational and social policies during the period of Labor government in 1997-2010. According to Kerr and Dyson [6], many of these initiatives have been robustly evaluated. However, they find that "overall ... the tenor of this evaluation evidence is not encouraging" ([6]: 6). Aside from education, there is widespread academic and professional consensus that ABIs in general "in terms of their stated or implicit aims ... have all been rather unsuccessful ... they have neither significantly improved the social and economic position of those living in the inner cities and peripheral estates nor have they succeeded in delivering the hoped-for economic revival" ([22]: 4). In education, research on "Educational Action Zones" for schools in disadvantaged areas shows that "relatively few of the program's original objectives were realized... Even in terms of attainment targets, there was little measurable improvement and in some EAZs there was even a negative zone effect" ([23]: 265).

In Germany, engagement with educational ABIs is more recent: During the last 10 years, a rich body of $A B I$ research has emerged. Initially, studies focused on achieving ABI goals at the level of the user, such as improved learning outcomes [24-26] or reduced social disadvantage [27]. Yet impacts were poor: Discussing social advantage, ([28]: 15) found that there is a "distinct gap between goal orientation and practical implementation." The most positive results can be found in studies from school development research focused on educational networks originating with schools as the nucleus (ibid.: 14), but even here, impacts are found to be very limited ([29]: 13).

Finally, since outcomes on the user level are too complex to be methodologically traced back to area-based interventions alone (ibid.; [30]: 6), the focus of research has shifted from evaluating goals on the user level to monitoring $\mathrm{ABI}$ structures and processes, analyzing network structures and partners, the quality of cooperation, etc. $([18,27,31-37]$ : 237).

Here too, there are gaps between intentions and implementation: Although those involved in ABIs seek a broader understanding of education beyond school, in practice, ABIs are characterized by a strong focus on schools ([28]: 35; [11]: 220; [38]: 22ff.; [17]: 29; [39]: 170). Although ABIs aim to encourage participation, there is very little participative decision-making ([33]: 246 [37];: 127).

Overall, ABI development has shifted from its initial user-level goals to matters of local educational management and cooperation on the structural level ([40]: 18; [9]: 106). Despite the ideal that networks should never be for networking alone ([30]: 61, see also [12, 37]), but are "only legitimate if they succeed in improving young people's lives" ([41, 42]: 287), Schmachtel and Olk ([28]: 30) conclude that ABIs are mired in a "Governance-trap" [43] and run the risk of "fail[ing] forward" [44]. Still, ABIs are regarded as leading reform concepts.

\section{Explanations}

After many evaluations and monitoring revealed this discrepancy between intentions and implementation, analytical studies focus on the reasons. Generally speaking, the gap can be traced back to simplistic assumptions 
about ABIs: While there is a consensus on ABI goals, there is little understanding of how to reach these goals and what factors influence them. One factor that has been seriously neglected is the influence of wider social contexts and structural conditions far beyond the scope of ABIs [6]. Duveneck [10] shows empirically that in the context of welfare state transformation, interurban competition affects the implementation of ABIs much more than the participants' intentions. Further, this influence explains why the broad understanding of education often becomes narrower and the intended participatory structures are not realized. Other studies also reveal the reproduction [45, 46, 28] and legitimization [47] of the very problems in welfare state transformation that $\mathrm{ABIs}$ intend to counteract.

Further, basic preconditions for cooperation have been neglected. Million et al. ([11]: 211ff) found that capacities for multi-professional cooperation are taken for granted. Evaluations provide evidence that professionals' lack of knowledge about each other's areas of work is a major problem within ABIs ([37]: 127). The fragmented German educational system offers very few occasions for professional exchange between local educational actors from different domains ([9]: 311ff.; [33]).

The concept of "rationalized myth" [48] provides an explanation for why these factors have been neglected and ABIs are transferred from model projects to wider regions even if they do not achieve their initial goals. Among the most popular analytical concepts in the field of ABIs (see [28]: 30), rationalized myths address approaches that build on assumptions (rather than evidence) that are so plausible it seems unnecessary to question or prove them. Even when they fail, it still seems more legitimate for institutions to maintain them than to adopt other approaches that are based on valid knowledge. Stolz et al. [49] first introduced this concept for ABI research, revealing the idea that networking improves quality within pedagogical institutions as a rationalized myth. Later, Schmachtel [50] added the functional character of rationalized myths in the context of welfare state transformation, showing how they mobilize resources for effective and efficient educational politics but contradict the initial goal requirements, and stressed the fact that resolving these myths is not a simple matter, given the crucial role of expectations for implementation. Finally, ABI research has shown that the first generation of ABIs was widely built on rationalized myth [46, 47, forthcoming, 52], which explains the gap between intentions and actual implementation.

\section{Research question}

To provide information about whether in times of transfer, ABIs will ultimately succeed or continue to "fail forward" the study investigates:
- What future developments are expected in 2030, and what developments are desired?

- How do expected developments relate to desirable developments? Is the discrepancy outlined above expected to remain in 2030 or to be resolved?

- Do expectations still follow rationalized myths, or are they replaced with knowledge and experience gained from 10 years of $\mathrm{ABI}$ development?

The next chapter outlines the study's empirical approach. Chapter 3 then presents the research findings on expected and desired ABI developments. After the data is interpreted in chapter 4 , the study draws conclusions about future ABI development.

\section{Empirical approach}

The Delphi method offers a nuanced approach to clarifying uncertain developments and providing an informational foundation to prevent undesirable developments [53]. It explicitly examines the relationship between desires and expectations and can be applied for different intentions such as in forecasts or policymaking. The method is based on the responses of a panel of experts, elaborates on their assumptions about future development and works with qualitative and quantitative designs. The Delphi method is applied in two rounds: In the first round, experts assess a range of statements about developments within their field, and they are able to add new aspects. In the second round, the results from first round are presented and the experts can then revise their answers based on this information ([53]: 45).

\section{Survey instrument}

Data collection was conducted via an online questionnaire based on a literature analysis of the ABI debate and a workshop with ten experts from nationwide $A B I$ research, practice, and programs. The discussion was transcribed and analyzed following Mayring's structured approach ([54]: 115). As a result, crucial fields of (uncertain) development in ABIs were identified, which are (in the order of the questionnaire):

- Goals of ABIs

- Drivers of development

- Challenges up to 2030

- Coordination and governance

- Cooperation and participation

- Funding and the understanding of education

- The role of ABIs as a concept for future development in education

Statements about possible developments were formulated and used as items for each field. 
Using a 6-point Likert scale, experts assessed the desirability and likelihood of developments in the fields mentioned above, except for challenges and drivers, where they only assessed likelihood. Additionally, the questionnaire asked for social-demographic data, expertise in ABIs and developments in different fields of areabased reform. It ended with a section for comments.

\section{Sampling}

The sample involves 180 nationwide experts on areabased education (for the definition of experts, see [55]: 470). Sampling started with a review of ABI literature, conferences, and official websites of ABIs as a starting point. The identified experts work in education, administration, politics, science, civil society, economy, and various other areas.

\section{Data collection}

Data collection took place from March to April and July to August of 2018. It started with an invitation sent to 851 experts via e-mail. Of these, 792 received the invitation and 315 participated in the first round. From this group, 197 participants took part in the second round. After the data was cleaned, 180 questionnaires remained on which the results are based (see Fig. 1).

\section{Data analysis}

Data analysis was conducted using SPSS 25. Comparing the results from the first and second rounds, there are only a few evident differences, but the percentage of respondents with "very high" subjective expertise increased from 12.1 to $14.4 \%$. The assessment of the desirability and likelihood of developments is indicated by statistical mean (M), the degree of consensus and divergence by standard deviation (SD).

To allow comparisons between different fields and concerning distinct groups, new scales were built regarding the constructs listed in Table 1. For every scale, internal consistency for desirability is worse than for likelihood.

For group comparisons, Mann-Whitney $U$ tests were used. To illustrate effect sizes "for determining the practical or theoretical importance of an effect" ([57]; p. 2), $U$ scores were converted to Cohen's $d$ [57], which is a measure of standardized mean difference: $d>0.2$ signifies a small effect, $d>0.5$ signifies a medium effect, and $d>0.8$ signifies a large effect [58]. For correlations, Spearman correlation coefficient $r$ was used: $r=0.1$ signifies a small effect, $r=0.3$ signifies a medium effect, and $r=0.5$ signifies a large effect [58].

\section{Sample structure}

The analysis of socio-demographic data and expertise in the field provides the following information.

The questionnaire asked experts to assign themselves to the fields in which they operate, allowing multiple answers. Among the respondents, 55 (30.6\%) indicated more than one field. The majority $(58.3 \%)$ deal with

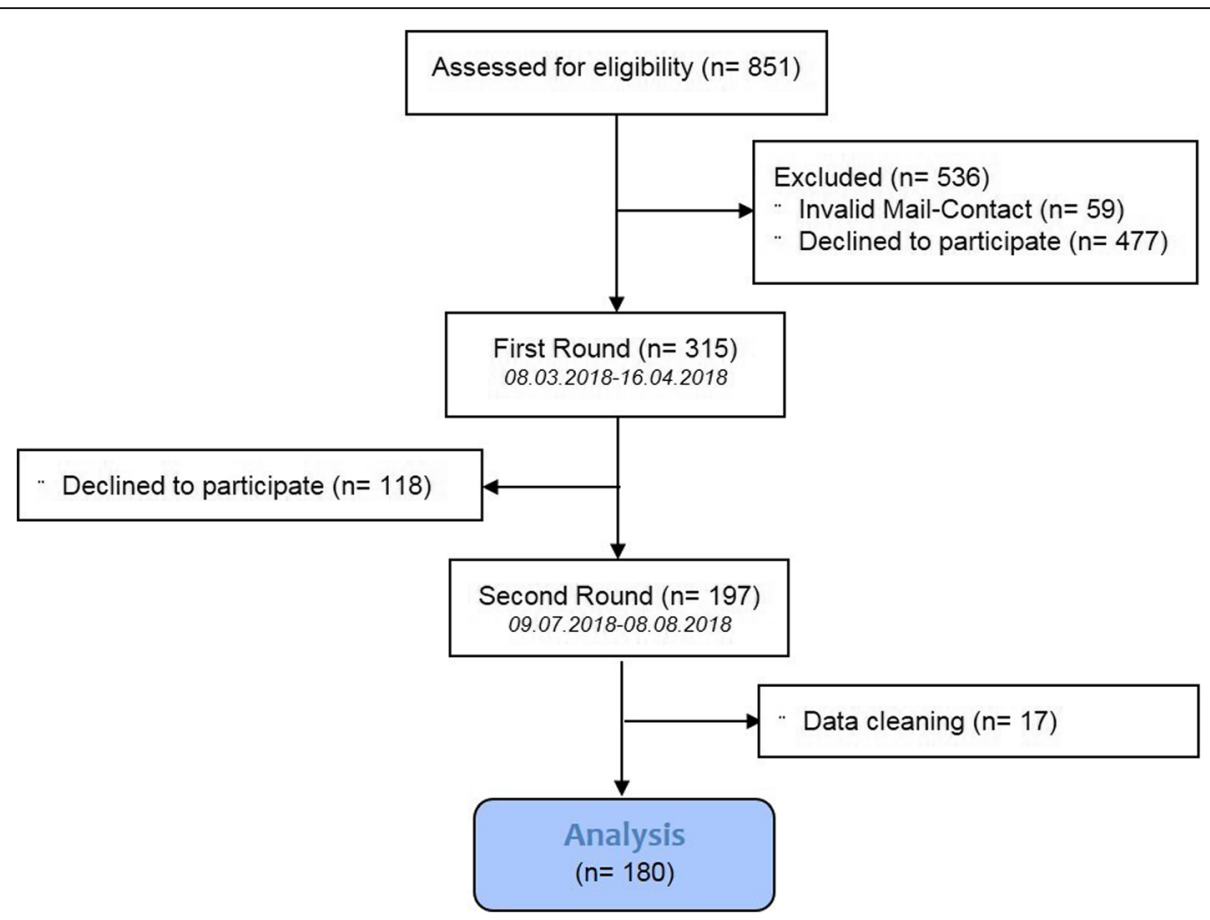

Fig. 1 Graphical representation based on CONSORT flow chart (see [56]) 
Table 1 Scales with their number of items and internal consistency based on Cronbach's alpha

\begin{tabular}{lll}
\hline Scale with number of items used & Desirability & Likelihood \\
\hline Goals (10) & $a=.817$ & $a=.857$ \\
Collaboration between actors (4) & $a=.546$ & $a=.813$ \\
Participation of citizens (7) & $a=.838$ & $a=.845$ \\
Coordination within established structures (5) & $a=.765$ & $a=.841$ \\
Overcoming established structures (7) & $a=.642$ & $a=.799$ \\
\hline
\end{tabular}

politics and administration, and of these 88 (48.9\% of the whole sample) work in local administration. Further, $28.9 \%$ work in education, with most in school development (9.4\%), or out-of-school education (6.1\%). Finally, $17.2 \%$ of participants works in research, $16.7 \%$ is active in civil society, and $5 \%$ in economics.

The experts are located in all federated states. However, there are regional differences: There is a higher representation of the states with a longer ABI tradition.

Approximately two thirds of the experts are women (64.4\%) and one third are male (35.6\%). The age of respondents ranges between 27 and 74 years $(M=48.3$ years, $S D=11.4$ years).

The degree of expertise is based on the form of work and amount of time spent on area-based education, the duration of activity in this field and a self-assessment. On average, the experts have worked in the field for 8.3 years $(S D=6.4$ years $)$. This corresponds with the initiation of a broad range of model projects, among them "Learning Locally." They spend $60.9 \%$ of their working hours on ABIs. Despite the high ratings of expertise, $9.4 \%$ of participants work as volunteers in the field.

Subjective expertise is positively correlated with years of work in the field $(r=.331, p<.001)$. The selfassessment of expertise was captured on a 6-point Likert scale from "very low" to "very high." The average selfassessment is located between "somewhat high" and "moderately high." Among respondents, 14.4\% rate their own expertise as very high, $7.2 \%$ as somewhat low $(M=$ 4.51; $S D=0.85$ ). No participant rated their own level of expertise as "moderately low" or "very low." On average, men rated their own expertise a little higher than women $(r=.162, p=.03)$. Additionally, $10 \%$ of the sample holds a doctorate degree and $2.9 \%$ are professors. Hence, one can assume the study is based on a high level of knowledge about processes and information in the development of area-based education.
To summarize, according to the research design, the sample is characterized by a high level of expertise, nationwide representation and a particular focus on local administration. Since local administration is highly relevant to ABIs, differences between those who work in this area and the rest of the sample were investigated in our analyses.

\section{Research findings}

The study seeks to identify the relationship between the perceived desirability and likelihood of developments in the future of ABIs as well as expectations alone. Results are divided into three sections.

- First, we present findings related to outcomes, that is, the impact ABIs are supposed to achieve for users (usually young people, but this can also be neighborhoods etc.).

- We then focus on governance aspects, first at the process level, which relates to developments in cooperation and participation, and then at the structural level, focusing not only on changes in coordination, governance, and funding in local administration but also the implementation of the ABI concept in general.

- Finally, expectations for the challenges and drivers of $\mathrm{ABIs}$ are presented.

Each section begins with a table giving an overview of the means and standard deviations $(\mathrm{M} \mid \mathrm{SD})$ from highest to lowest desirability. Additionally, for easy comprehension, the means are visualized with graphic illustrations (Table 2).

\section{Desirability and expectations of $\mathrm{ABI}$ development}

The study reveals that the relation between desires and expectations is characterized by a general pattern. While most developments are rated as very desirable or desirable, they are rated as only somewhat likely. Standard deviations are higher in respect to likelihood than to desirability, which might reflect a strong consensus on the desired direction of change.

\section{Outcomes}

The fields associated with user-level outcomes are goals of ABIs and the understanding of education. Here, the difference between desirability and likelihood is particularly pronounced. Developments in both fields are characterized

Table 2 Visualization of means

\begin{tabular}{|c|c|c|c|c|c|c|}
\hline Illustration & --- & -- & - & + & ++ & +++ \\
\hline Mean & $1-1.49$ & $1.5-2.49$ & $2.5-3.49$ & $3.5-4.49$ & $4.5-5.49$ & $5.5-6$ \\
\hline Meaning & $\begin{array}{l}\text { Very unlikely/ } \\
\text { undesirable } \\
\text { (1) }\end{array}$ & $\begin{array}{l}\text { Moderately } \\
\text { unlikely/undesirable } \\
\text { (2) }\end{array}$ & $\begin{array}{l}\text { Somewhat unlikely/ } \\
\text { undesirable } \\
\text { (3) }\end{array}$ & $\begin{array}{l}\text { Somewhat } \\
\text { likely/desirable } \\
\text { (4) }\end{array}$ & $\begin{array}{l}\text { Moderately } \\
\text { likely/desirable } \\
\text { (5) }\end{array}$ & $\begin{array}{l}\text { Very likely/ } \\
\text { desirable } \\
\text { (6) }\end{array}$ \\
\hline
\end{tabular}


by particularly high desirability, while their implementation in practice is rated as less likely.

ABI goals Statements on ABI goals primarily relate to education, though they vary in their focus on young people or on cooperation among local actors within education. One item refers to outcomes for cities and regions (Table 3).

Experts widely agree on the goals of ABIs and rate most of them as "very desirable," while all developments are considered only "somewhat likely." This general discrepancy between what is desirable and what is likely also becomes evident in the aggregation of different goals of area-based education (Fig. 2): Every participant rates the average desirability higher than the likelihood. On average, the goals of area-based education are strongly desirable $(M=5.79 ; S D=0.27)$. At the same time, the experts rate the probability of achieving those aims much lower $(M=4.16$; $S D=0.52)$.

To put this discrepancy into perspective statistically: On the 6-point Likert scale, in $96.4 \%$ of the sample, the difference between desirability and likelihood of the goals is at least 1 , in $60.9 \%$ it is at least 1.5 , and in $21.3 \%$ it is at least 2 .

The characteristic relation between desirability and likelihood of individual items is illustrated for school dropout rates in absolute numbers (Fig. 3).
There are only two exceptions to this general pattern among the individual items: The statement focusing on outcomes for cities and regions (rather than education, local actors, or young people) is only "moderately desirable" $(M=5.37 ; S D=0.71)$, and the item on increased university entrance certificates is only "somewhat desirable" $(M=4.41 ; S D=0.84)$.

Understanding of education in ABIs Experts assessed items on the development of the educational understanding within ABIs in 2030 (Table 4).

This shows a more varied pattern. The five most desirable items reflect the discrepancy between "very desirable" or "moderately desirable" and only "somewhat likely" developments. However, in two cases, there is no discrepancy: The statements about support for successful learning outcomes and compensation for deficits are moderately desirable and moderately likely or somewhat desirable and somewhat likely, respectively. Interestingly, for education understood as school-based learning, the relation is inverted: It is rated as the most likely of all the statements but is the only item that is "somewhat undesirable."

The discrepancy between desirable and likely development is most evident for responses about progress in expanding education (Table 5). It is "very desirable" in a

Table 3 Means and standard deviations for statements on ABI goals

\begin{tabular}{|c|c|c|}
\hline Goals: In $2030, \ldots$ & Desirability & Likelihood \\
\hline ... transitions along the educational biography are coordinated. & $\begin{array}{l}+++ \\
5.91 \mid 0.31\end{array}$ & $\begin{array}{l}+ \\
4.12 \mid 0.66\end{array}$ \\
\hline ... vulnerable young people benefit from individual support. & $\begin{array}{l}+++ \\
5.90 \mid 0.30\end{array}$ & $\begin{array}{l}+ \\
3.97 \mid 0.65\end{array}$ \\
\hline ... the ideal of equal opportunities has been approached. & $\begin{array}{l}++++ \\
5.85 \mid 0.42\end{array}$ & $\begin{array}{l}+ \\
3.94 \mid \\
0.66\end{array}$ \\
\hline ... ABls are an instrument to reduce educational disadvantage. & $\begin{array}{l}\stackrel{+++}{5.82} \mid 0.40\end{array}$ & $\begin{array}{l}+ \\
4.29 \mid\end{array}$ \\
\hline ... there is a politically accepted, reliable educational infrastructure. & $\begin{array}{l}\stackrel{+++}{++} \\
5.81 \mid 0.43\end{array}$ & $\begin{array}{l}+ \\
4.10 \mid \\
0.66\end{array}$ \\
\hline ... the school dropout rate has declined in ABIs. & $\begin{array}{l}\stackrel{+++}{++} \\
5.80 \mid 0.49\end{array}$ & $\begin{array}{l}+ \\
4.15 \mid 0.77\end{array}$ \\
\hline ... citizens know about local learning and educational opportunities. & $\begin{array}{l}\stackrel{+++}{++} \\
5.80 \mid 0.42\end{array}$ & $\begin{array}{l}+ \\
4.14 \mid 0.70\end{array}$ \\
\hline ... local actors act as a "responsible community." & $\begin{array}{l}+++ \\
5.77 \mid 0.45\end{array}$ & $\begin{array}{l}+ \\
4.27 \mid 0.76\end{array}$ \\
\hline ... local actors act within professional learning networks. & $\begin{array}{l}\stackrel{+++}{++} \\
5.71 \mid 0.50\end{array}$ & $\begin{array}{l}+ \\
4.32 \mid\end{array}$ \\
\hline ... educational institutions conduct systematic quality development. & $\begin{array}{l}\stackrel{+++}{5.60 \mid} 0.60 \\
5.60\end{array}$ & $\begin{array}{l}+ \\
3.66 \mid \\
\mid\end{array}$ \\
\hline ... more people in ABls use learning opportunities than elsewhere. & $\begin{array}{l}+++ \\
5.57 \mid 0.61\end{array}$ & $\begin{array}{l}+ \\
4.41 \mid\end{array} 0.62$ \\
\hline ... ABIs raise the attractiveness of cities/regions. & $\begin{array}{l}++ \\
5.37 \mid 0.71\end{array}$ & $\begin{array}{l}+ \\
4.57 \mid 0.74\end{array}$ \\
\hline ... more people receive university entrance certificates. & \begin{tabular}{l|l}
+ & \\
4.41 & 0.84
\end{tabular} & $\begin{array}{l}+ \\
3.78 \\
\end{array}$ \\
\hline
\end{tabular}




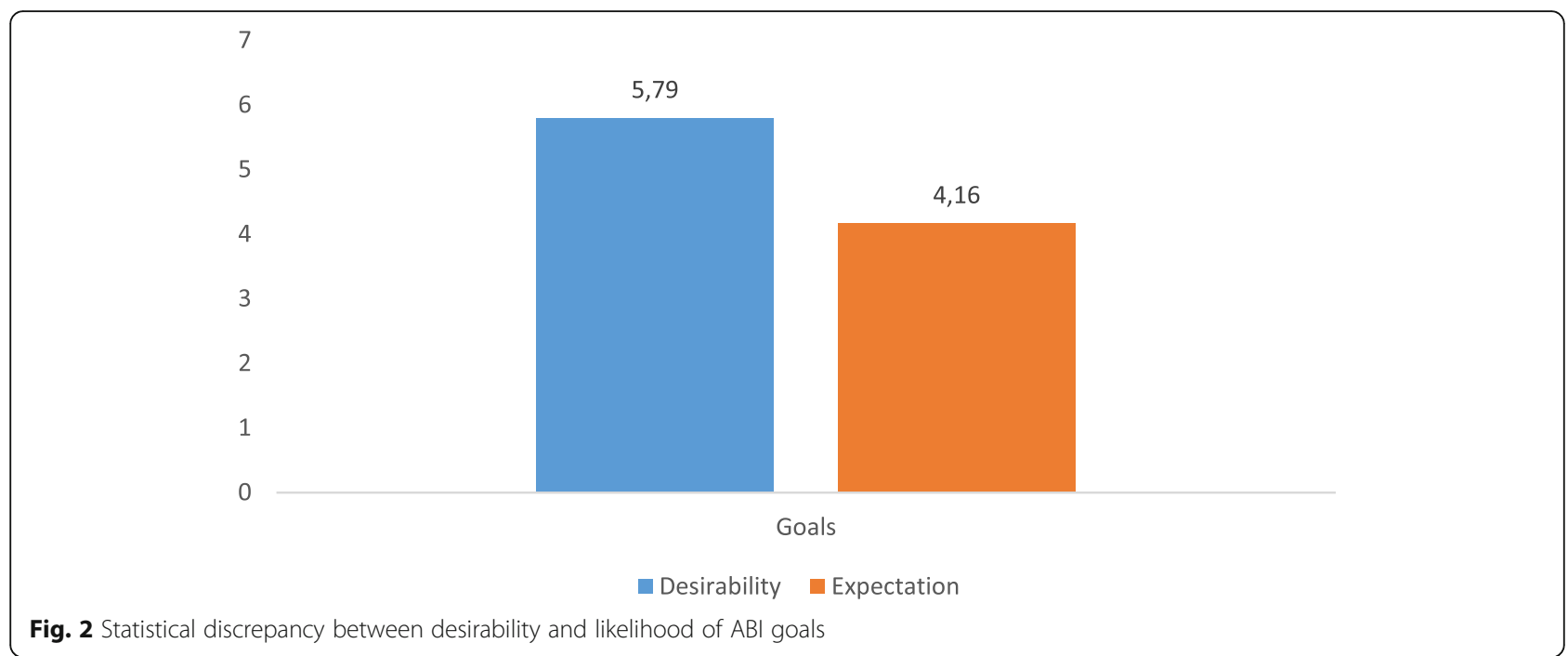

qualitative dimension (that is, a balance between formal and non-formal education with a focus on young people's capabilities), but "somewhat unlikely." In contrast, expanding education in a functional dimension (that is, along the formal educational biography, focusing on the needs of changed labor markets) is "moderately likely" but only somewhat desirable. Effect sizes between what is desirable and what is likely are very large $\left(d_{\text {qualitative di- }}\right.$ mension $=3.03 ; d_{\text {functional dimension }}=1.30$ ).

To summarize, with respect to outcomes, there is a significant pattern of "moderately desirable" or even "very desirable" developments that are considered only "somewhat likely." However, this pattern is reversed for items related to formal education: Here, the development is considered more likely but less desirable.

\section{Processes}

Developments in terms of processes relate to aspects of the organization of education in ABIs, namely, cooperation and participation. Both aspects are presented and then compared.

Cooperation Items in this battery focus on multiprofessional cooperation among professionals in education or administration (Table 6). The grayed-out item is not taken into consideration here but used in the participation scale for comparison (see below).

As was the case for ABI goals, developments are "very desirable" or at least "moderately desirable" and "somewhat likely."

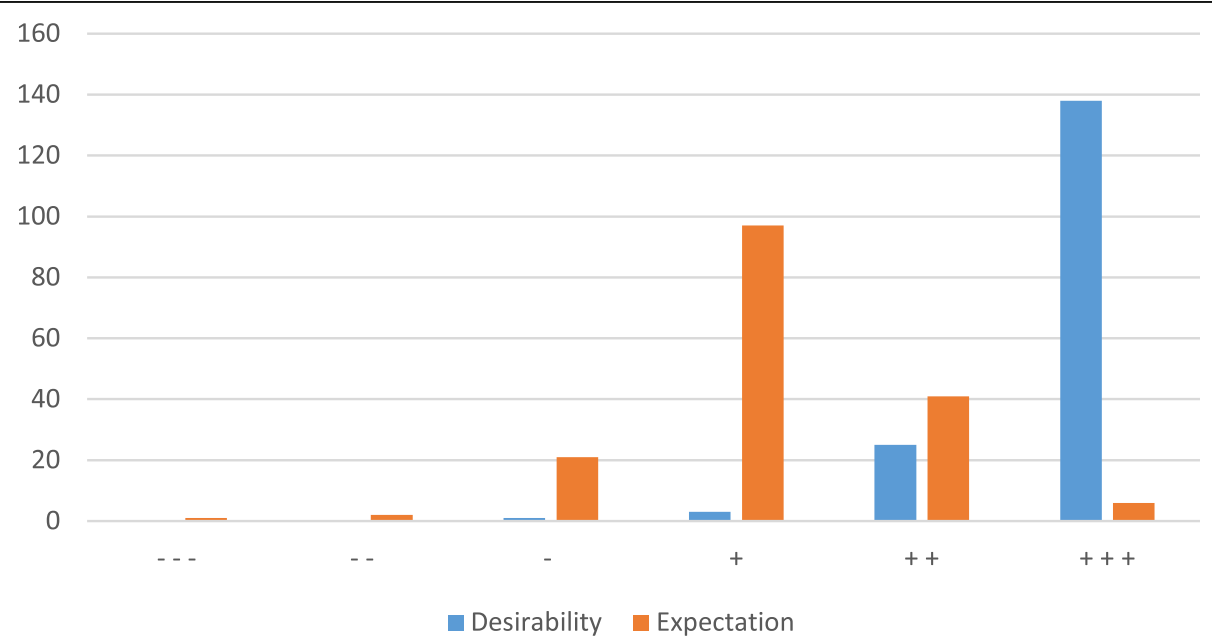

Fig. 3 Desirable and likely developments for dropout rates in area-based education initiatives 
Table 4 Means and standard deviations for statements on ABI understanding of education

\begin{tabular}{|c|c|c|}
\hline In 2030 , education is understood as ... & Desirability & Likelihood \\
\hline ... lifelong learning along the educational biography. & $\begin{array}{l}++++ \\
5.72 \mid 0.50\end{array}$ & $\begin{array}{l}+ \\
4.35 \mid\end{array}$ \\
\hline ... improvement of socio-spatial living conditions. & $\begin{array}{l}+++ \\
5.66 \mid 0.59\end{array}$ & $\begin{array}{l}+ \\
3.74 \mid 0.80\end{array}$ \\
\hline $\begin{array}{l}\text {... self-education as a crucial resource for competencies } \\
\text { for conduct of life. }\end{array}$ & $\begin{array}{l}++ \\
5.49 \mid 0.67\end{array}$ & $\stackrel{+}{+} .96 \mid 0.75$ \\
\hline ... acquiring social competencies. & 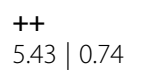 & $\begin{array}{l}+ \\
4.24 \mid\end{array} \mid .76$ \\
\hline ... successful coping with educational transitions. & $\begin{array}{l}++ \\
5.03 \mid 0.78\end{array}$ & $\begin{array}{l}+ \\
4.52 \mid 0.74\end{array}$ \\
\hline ... support for successful learning outcomes. & $\begin{array}{l}++ \\
4.47 \mid 0.81\end{array}$ & $\begin{array}{l}++ \\
4.62 \mid 0.81\end{array}$ \\
\hline ... compensation for deficits in competencies. & $\begin{array}{l}+ \\
4.29 \mid\end{array} 0.94$ & $\begin{array}{l}+ \\
4.02 \mid\end{array} 0.72$ \\
\hline ... school-based learning. & $3.24 \mid 0.93$ & $\begin{array}{l}++ \\
4.62 \mid 0.84\end{array}$ \\
\hline
\end{tabular}

Participation In contrast to cooperation, participation relates to users rather than to professionals, and includes one reversed item stating that there are no attempts to promote participation (Table 7).

Here, answers are slightly more pessimistic: While most items (including the reversed item) correspond to the basic pattern, items concerning professional structures for direct democracy and area-based initiatives as participatory initiatives are "somewhat unlikely." Interestingly, again, the most likely development is "moderately undesirable:" The statement that "there will be models for participation, but decisions will continue to be made topdown." Again, effect sizes between desirability and likelihood are large $(d=3.54 ; d=3.64)$.

Comparison To compare the development of cooperation and participation in more detail, the two batteries were transformed into scales (see above). As illustrated in Fig. 4, analysis shows that cooperation between professionals is not only considered more likely than participation of citizens $\left(M_{\text {cooperation }}=4.05 ; M_{\text {participation }}=3.65\right)$ but is also more desirable $\left(M_{\text {cooperation }}=5.84 ; M_{\text {participa- }}\right.$ tion $=5.37$ ).

Among the sample, experts with high subjective expertise want both cooperation $(r=.259 ; p=.001)$ and participation $(r=.156 ; p=.042)$ more than those with lower expertise, and they also consider both aspects more likely $\left(r_{\text {cooperation }}=.171 ; p=.026 ; r_{\text {participation }}=\right.$ $.159 ; p=.037)$. Similar results emerge when experts working within local administration are compared to those who do not: The former also rate cooperation and participation as more probable $\left(d_{\text {cooperation }}=0.45 ; p=\right.$ $\left..006 ; d_{\text {participation }}=0.33 ; p=.045\right)$. Regarding desirability, they want cooperation slightly more $(d=0.20 ; p=.155)$ and participation slightly less $(d=0.27 ; p=.090)$ than experts who do not work in local administration, but these group differences are not statistically significant.

\section{Structural aspects}

Finally, desirability and likelihood of structural developments were captured. The analysis here considers developments in coordination/governance and funding. Based on this, overarching scales for the coordination or replacement of established structures were constructed and compared. The respective items are indicated with a ${ }^{\mathrm{C}}$ for coordination and an ${ }^{\mathrm{R}}$ for replacing given structures.

Coordination/governance Items here relate to developments of structures for coordinating ABI activities in the sense of governance (Table 8). The top four items relate to coordination, the rest to replacing established structures.

Table 5 Means and standard deviations for statements on expanding education

\begin{tabular}{|c|c|c|}
\hline In 2030 , there is a broader understanding of education ... & Desirability & Likelihood \\
\hline $\begin{array}{l}\text {...in a qualitative dimension: balance between formal and non-formal } \\
\text { education with a focus on young people's capabilities. }\end{array}$ & $\begin{array}{l}+++ \\
M=5.59 \\
S D=0.68\end{array}$ & $\begin{array}{l}\bar{M}=3.50 \\
S D=0.70\end{array}$ \\
\hline $\begin{array}{l}\text {... in a functional dimension: along the formal educational biography, } \\
\text { focusing on the needs of changed labor markets. }\end{array}$ & $\begin{array}{l}+ \\
M=3.64 \\
S D=0.96\end{array}$ & $\begin{array}{l}++ \\
M=4.70 \\
S D=0.64\end{array}$ \\
\hline
\end{tabular}


Table 6 Means and standard deviations for statements on coordination and governance among educational actors

\begin{tabular}{|c|c|c|}
\hline Coordination/Governance: In 2030... & Desirability & Likelihood \\
\hline $\begin{array}{l}\text {... actors from schools, non-formal education and local } \\
\text { administration cooperate systematically. }\end{array}$ & $\begin{array}{c}++++ \\
5.91 \mid 0.29\end{array}$ & $4.20 \stackrel{+}{0.70}$ \\
\hline ... multi-professional teams are working in schools. & $\begin{array}{c}+++ \\
5.89 \mid 0.34\end{array}$ & $\stackrel{+}{+}$ \\
\hline $\begin{array}{l}\text {... all-day schools show a variety of learning opportunities and } \\
\text { innovative approaches. }\end{array}$ & $\begin{array}{c}++++ \\
5.80 \mid 0.51\end{array}$ & $\stackrel{+}{+}$ \\
\hline $\begin{array}{l}\text {... there is cooperation between education and other fields of local } \\
\text { administration such as social politics or regional development. }\end{array}$ & $\begin{array}{c}+++ \\
5.76 \mid 0.46\end{array}$ & $3.59 \stackrel{+}{0} 0.74$ \\
\hline $\begin{array}{l}\text {... there is user-level participation (young people, parents, } \\
\text { neighbors) }\end{array}$ & $5.17 \mid 0.66$ & $3.34 \mid 0.70$ \\
\hline $\begin{array}{l}\text {... educational actors retain their professional and institutional } \\
\text { autonomy. }\end{array}$ & $4.59 \mid+0.71$ & $\stackrel{+}{+}$ \\
\hline
\end{tabular}

A clear pattern emerges for the individual items: Those with a focus on cooperation show the same pattern seen elsewhere of "very desirable" or "moderately desirable" and "somewhat likely," while assessments on items related to replacing established structures are more pessimistic: They are also rated as "moderately desirable," but "somewhat unlikely" or even "moderately unlikely."

Funding As above, individual items on funding relate to the coordination or replacement of (separate) funding structures, except for statements on changes like raised budgets or cost-neutrality and one item is reversed (Table 9).

In the context of funding, the experts' assessments are the most pessimistic among all batteries. Aside from one item on a budget for professionals and material expenses, developments are considered "somewhat unlikely." Further, except for the same item, desirability is slightly lower here; all other items are only "moderately desirable" or "somewhat desirable." As it is "somewhat unlikely" but also "very undesirable" that there will be no resources for coordination, there is a slight optimism on the reversed item. Further, group comparison shows that experts working in local administration assess the budget for positions/equipment as more probable.

Comparison Based on the results for coordination and funding, an overarching scale was constructed for items concerning Coordination within given structures and Replacing given structures. When comparing the two, strong statistical differences become evident (Fig. 5).

Table 7 Means and standard deviations for statements about participation with civil society

\begin{tabular}{|c|c|c|}
\hline Participation: In 2030, ... & Desirability & Likelihood \\
\hline ... there are instruments for needs-orientation. & $\begin{array}{l}++++ \\
5.72 \mid 0.51\end{array}$ & $\begin{array}{l}+ \\
+ \\
4.04 \mid\end{array} 0.67$ \\
\hline $\begin{array}{l}\text {... participation is supported by low-threshold accesses } \\
\text { (e.g., information in simple language). }\end{array}$ & $\begin{array}{l}+++ \\
5.56 \mid 0.57\end{array}$ & $\begin{array}{l}+ \\
4.01 \mid\end{array} \mid .70$ \\
\hline ... ABls are oriented toward dialog with their target groups. & $\begin{array}{l}++ \\
5.44 \mid 0.61\end{array}$ & $\begin{array}{l}+ \\
3.53 \mid\end{array} 0.71$ \\
\hline ... acceptance is analyzed before projects are realized. & $\begin{array}{l}++ \\
5.40 \mid 0.66\end{array}$ & $\begin{array}{l}+ \\
4.02 \mid\end{array} 0.71$ \\
\hline ... there are professional structures for direct democracy in ABls. & $\begin{array}{l}++ \\
5.18 \mid 0.65\end{array}$ & $\overline{3.19} \mid 0.77$ \\
\hline ... professional facilitators support participative processes. & $\begin{array}{l}++ \\
5.17 \mid 0.68\end{array}$ & $\begin{array}{l}+ \\
3.83 \mid\end{array} 0.78$ \\
\hline ... there are no attempts to encourage citizens to participate in ABIs. & $--\overline{0} \mid 0.88$ & $-\overline{3.11} \mid 0.78$ \\
\hline ... ABls are participatory initiatives. & $\begin{array}{l}++ \\
5.13 \mid 0.71\end{array}$ & $\begin{array}{l}- \\
3.40\end{array} \mid 0.76$ \\
\hline $\begin{array}{l}\text {... there will be models for participation, but decisions will continue } \\
\text { to be made top-down. }\end{array}$ & \begin{tabular}{l|l}
-- \\
2.49 & 1.02
\end{tabular} & $\begin{array}{l}++ \\
4.59 \mid 0.72\end{array}$ \\
\hline
\end{tabular}




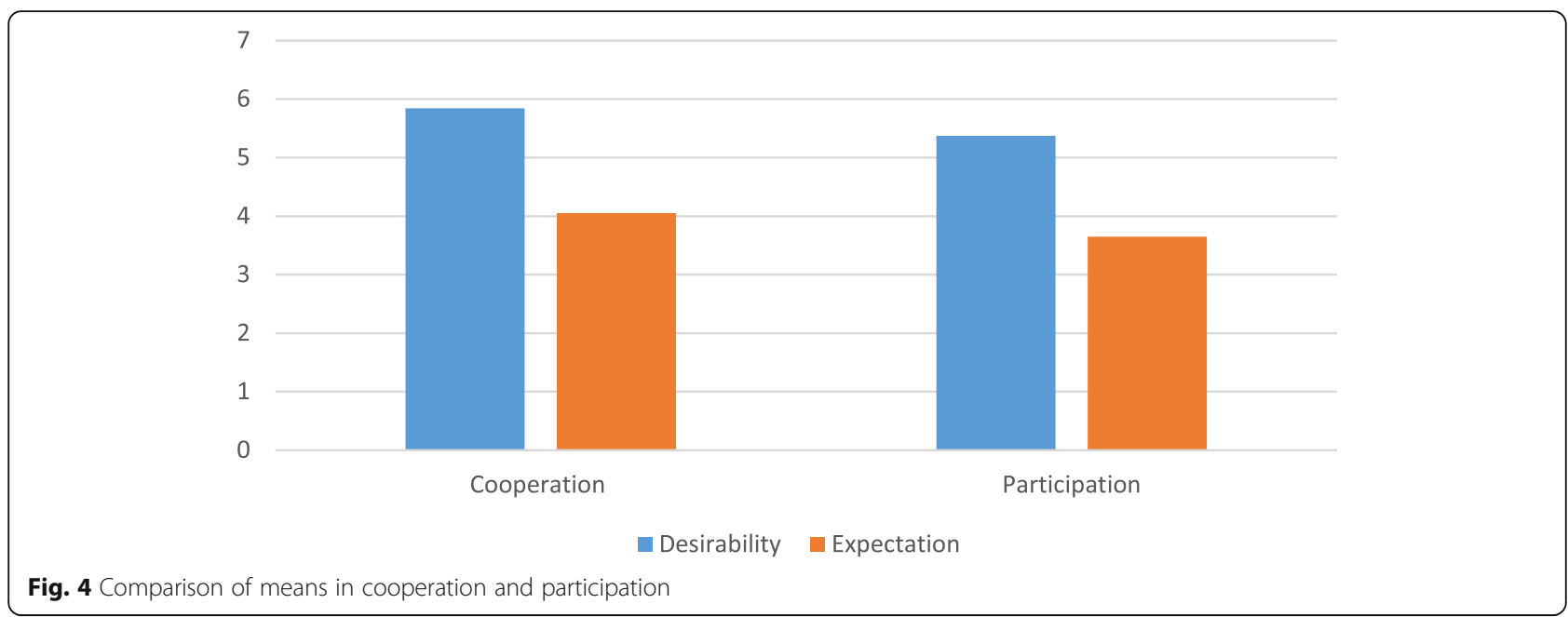

Statistically, experts want coordination within established structures more than they want to replace them $(d=1.84 ; p<.001)$. They also consider coordination within established structures more likely than replacement $(Z=-11.359 ; p<.001 ; d=1.92)$. Again, there is a connection with subjective expertise. The higher the subjective expertise, the higher participants rate the probability of coordination within established structures in the future $(r=.24 ; p=.002)$.

\section{ABIs as reform models}

Finally, the study asks participants to assess ABIs as a model for coping with challenges in education (Fig. 6).

The results reflect the typical pattern: For the majority, it is very desirable (78.6\%) and for all participants at least "somewhat desirable" (4.8\%) that ABIs become a model to cope with challenges in education $(M=5.74 ; S D=$ 0.54). However, this statement is considered much less likely to be valid in 2030: Most assessments are either "moderately likely" (29.4\%) or "somewhat likely" (61.2\%), but some consider it "somewhat unlikely." This discrepancy has a very large effect size $(d=3.96)$. Yet, in absolute terms, it is "somewhat likely" to be achieved $(M=4.25 ; S D=0.62)$.

Interestingly, the higher the subjective expertise, the more likely it seems to the experts that the aims of areabased education will be achieved $(r=.167 ; p=.029)$. The effect size of this correlation is small.

\section{Expectations for future development}

Finally, experts were asked to assess the likelihood that certain ABI challenges will remain in 2030 and to what degree certain drivers are expected to influence future development.

\section{Challenges}

The results begin with challenges that have been identified for ABIs (Table 10).

Table 8 Means and standard deviations of statements on coordination and governance in ABls

\begin{tabular}{|c|c|c|}
\hline Coordination/governance: In $2030, \ldots$ & Desirability & Expectation \\
\hline ... there are committed support structures for $A B I$ coordination and governance. ${ }^{C}$ & $\begin{array}{l}+++ \\
5.64 \mid 0.55\end{array}$ & $\begin{array}{l}+ \\
3.76 \mid\end{array} 0.67$ \\
\hline$\ldots$ there is a central authority for $\mathrm{ABI}$ coordination and governance. ${ }^{\mathrm{C}}$ & $\begin{array}{l}+++ \\
5.63 \mid 0.58\end{array}$ & $+\frac{+}{3.98} \mid 0.73$ \\
\hline $\begin{array}{l}\text {... strategic-responsive educational management is part of modern local } \\
\text { administration. }\end{array}$ & $\begin{array}{l}+++ \\
5.57 \mid 0.63\end{array}$ & $\begin{array}{l}+ \\
3.79\end{array} \mid 0.80$ \\
\hline$\ldots$ the roles and responsibilities of $A B I$ actors are reshaped. ${ }^{C}$ & $\begin{array}{l}++ \\
5.08 \mid 0.63\end{array}$ & $\begin{array}{l}+ \\
3.71 \mid 0.69\end{array}$ \\
\hline ... education and social politics are connected on a local level. ${ }^{R}$ & $\begin{array}{l}++ \\
4.99\end{array} 0.73$ & $\begin{array}{l}- \\
3.26\end{array} \mid 0.77$ \\
\hline$\ldots$ the school and youth systems are joined. ${ }^{R}$ & $\begin{array}{l}++ \\
4.57 \mid 0.92\end{array}$ & $\overline{2.78} \mid 0.82$ \\
\hline local states are responsible for internal and external school matters. ${ }^{R}$ & $\begin{array}{l}++ \\
4.14 \mid 1.02\end{array}$ & $\overline{2.17} \mid 0.76$ \\
\hline
\end{tabular}


Table 9 Means and standard deviations for statements on ABI funding

\begin{tabular}{|c|c|c|}
\hline Funding: In 2030, ... & Desirability & Expectation \\
\hline ... there will be a budget for professionals and material expenses. ${ }^{c}$ & $\begin{array}{l}++++ \\
5.78 \mid 0.44\end{array}$ & $\begin{array}{l}+ \\
3.82 \mid\end{array} 0.80$ \\
\hline ... budgets for school and child-care have been raised by more than $50 \%$. & $\begin{array}{l}++ \\
5.43 \mid\end{array} 0.69$ & $\overline{2.61 \mid} 0.92$ \\
\hline ... there is a socio-spatial budgeting. ${ }^{R}$ & $\begin{array}{l}++ \\
5.40 \mid\end{array} 0.67$ & $\overline{3.14} \mid 0.80$ \\
\hline$\ldots$ there has been a fundamental change in local educational funding. ${ }^{R}$ & $\begin{array}{l}++ \\
5.16 \mid 0.66\end{array}$ & $\overline{2.60} \mid 0.79$ \\
\hline $\begin{array}{l}\text {... expenses for parenting assistance have been reduced by restructuring } \\
\text { of local educational support and prevention. }\end{array}$ & $\begin{array}{l}++ \\
5.10 \mid\end{array} 0.77$ & $\overline{3} .02 \mid 0.70$ \\
\hline $\begin{array}{l}\text {... responsibilities for and decisions about school and child-care are from } \\
\text { the "same hand". }\end{array}$ & $\begin{array}{l}++ \\
4.67 \mid 0.83\end{array}$ & $\overline{-} .64 \mid 0.82$ \\
\hline $\begin{array}{l}\text {... private capital will be collected for public educational institutions } \\
\text { (a trust for educational innovations). }{ }^{\text {R }}\end{array}$ & $\stackrel{+}{+} 3.96 \mid 1.15$ & $\overline{2} .73 \mid 0.77$ \\
\hline$\ldots \mathrm{ABI}$ development is cost-neutral. & $\stackrel{+}{3.44 \mid} 1.04$ & $\overline{2} .44 \mid 0.77$ \\
\hline ... there will be no resources for continuation of coordination. & $\overline{--}$ & $\overline{3} .00 \mid 0.75$ \\
\hline
\end{tabular}

Most strikingly, all challenges are at least "somewhat likely" to remain over the next 10 years. Both statements that are "moderately likely" relate to long-term funding. Further, compared to other fields, responses here show the highest standard deviations $(S D=0.78-1.00$ in contrast to, for example, $S D_{\text {Aims }}=0.653-0.779 ; S D_{\text {Participation }}=0.699-$ 0.771). This indicates that the experts' assessments are more diverse and therefore future challenges are more uncertain. The group dealing with local education rates the challenges as more likely to remain $(d=0.34 ; p=.035)$.

\section{Drivers}

Finally, experts assessed their expectations for the impact of different drivers of ABI development (Table 11).
All drivers identified in ABI literature were assessed as "moderately likely" to have an impact on ABI development $\left(M_{\text {Drivers }}=4.99\right)$, except for "civil society" which is only "somewhat likely." The drivers of ABI development with the highest expected impact are decision-makers from administration and politics who are responsible for adequate structures.

In sum, results on challenges and drivers indicate long-term perspectives in the stage of transfer.

\section{Data interpretation}

First, the data reveals adapted expectations for ABI development. The overall pattern of moderately desirable or very desirable developments that are considered only somewhat likely marks a contrast to the early

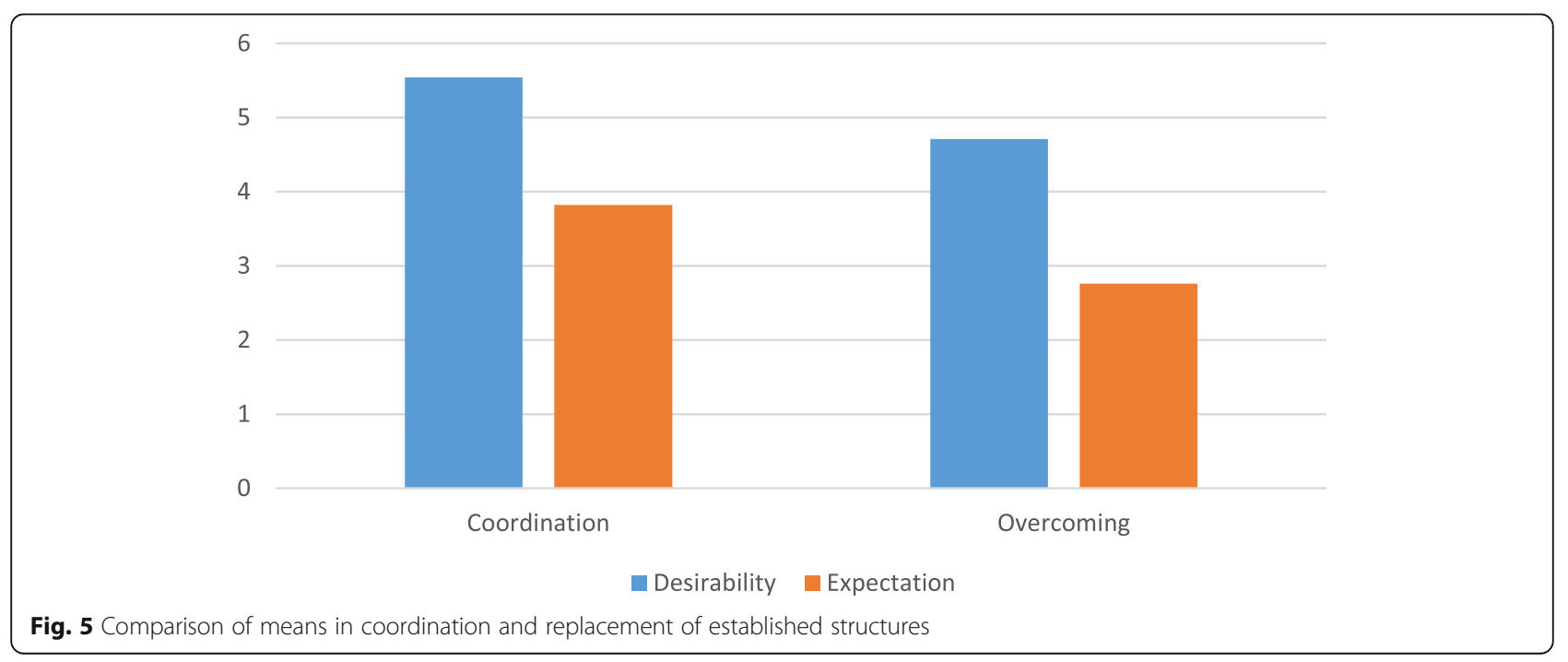




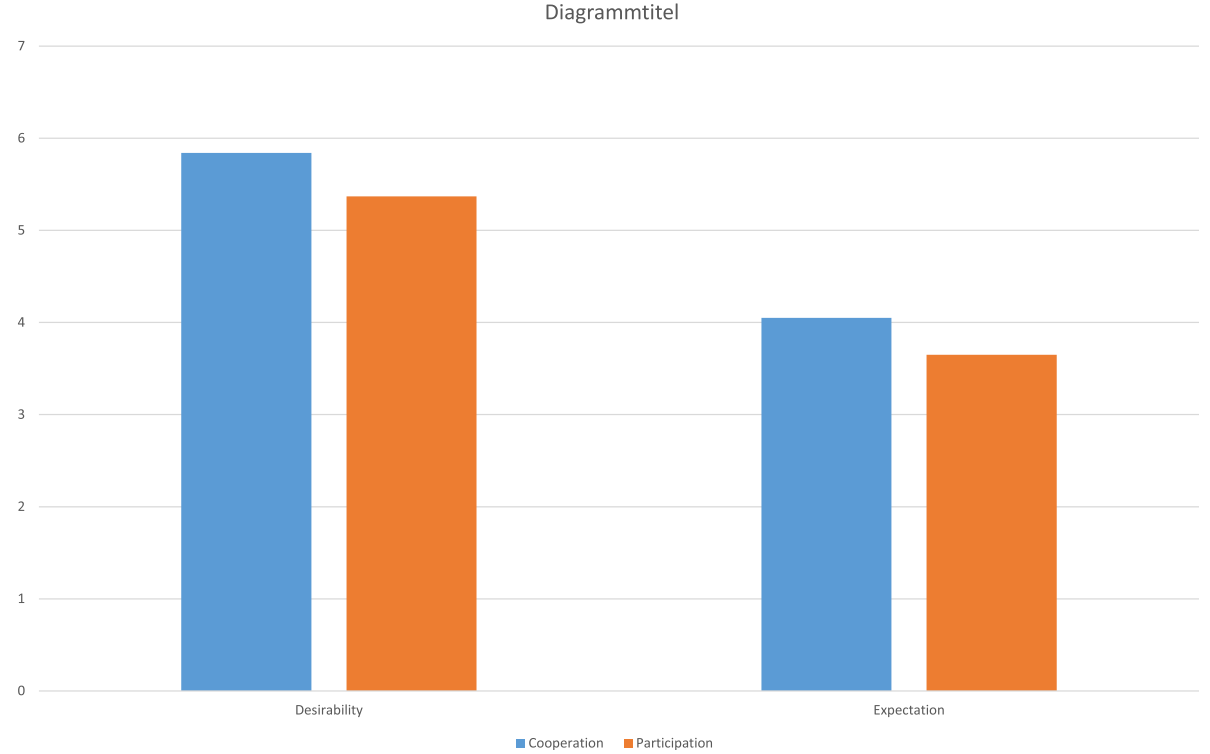

Fig. 6 Desirable and likely developments in ABls as reform models for coping with challenges in education

debate, which was characterized by high expectations for the potential of ABIs at the user level. After 10 years of experience, the respondents do not expect to achieve this potential in 2030 as much as they wish, and regarding the understanding of education, they even expect to see fewer desirable developments in formal aspects of education and an expansion of the functional dimension.

Table 10 Means and standard deviations of $A B I$ challenges

\begin{tabular}{|c|c|}
\hline Challenges: In 2030, ... & Likelihood \\
\hline $\begin{array}{l}\text {... project structures will not exist beyond } \\
\text { project funding. }\end{array}$ & $\begin{array}{l}++ \\
4.64 \mid 0.85\end{array}$ \\
\hline $\begin{array}{l}\text {... cooperation and coordination are } \\
\text { impeded as voluntary "add-ons." }\end{array}$ & $\begin{array}{l}++ \\
4.66 \mid\end{array} 0.78$ \\
\hline $\begin{array}{l}\ldots \text { there are lacking legal jurisdictions } \\
\text { limiting transition management. }\end{array}$ & $\begin{array}{l}+ \\
4.32 \mid\end{array} 0.79$ \\
\hline ... outcomes of ABls are hard to measure. & $\begin{array}{l}+ \\
4.22 \mid\end{array} 0.95$ \\
\hline $\begin{array}{l}\text {... actors in non-formal education feel } \\
\text { neglected due to the school focus. }\end{array}$ & $\begin{array}{l}+ \\
4.02 \mid\end{array} 0.97$ \\
\hline $\begin{array}{l}\text {... educational monitoring serves to } \\
\text { legitimate but not to influence decision } \\
\text { making. }\end{array}$ & $\begin{array}{l}+ \\
3.99 \mid \\
3.00\end{array}$ \\
\hline $\begin{array}{l}\text {... actors' motivation is reduced by lacking } \\
\text { incentives. }\end{array}$ & $\begin{array}{l}+ \\
3.92 \mid\end{array} 0.96$ \\
\hline $\begin{array}{l}\ldots \text { there are conflicts revolving around } \\
\text { functional/economic interests in education. }\end{array}$ & $\begin{array}{l}+ \\
3.74 \mid\end{array} \mid .98$ \\
\hline $\begin{array}{l}\text {... competition between educational actors } \\
\text { affects cooperation negatively. }\end{array}$ & $\begin{array}{l}+ \\
3.73 \mid \\
\end{array} .84$ \\
\hline $\begin{array}{l}\ldots \text { there are problems coming to agreement } \\
\text { on common visions. }\end{array}$ & $\begin{array}{l}+ \\
3.63 \mid\end{array} 0.88$ \\
\hline $\begin{array}{l}\text {... local educational management fails because } \\
\text { of bureaucracy. }\end{array}$ & $\begin{array}{l}+ \\
3.54 \mid 0.91\end{array}$ \\
\hline
\end{tabular}

Table 11 Means and standard deviation of $A B I$ drivers

\begin{tabular}{|c|c|}
\hline Drivers: The impact of ... & Likelihood \\
\hline ... decision-makers & $\begin{array}{l}+++ \\
5.45 \mid 0.68\end{array}$ \\
\hline ... planning security & $\begin{array}{l}++ \\
5.32 \mid 0.76\end{array}$ \\
\hline ... local coordinators & $\begin{array}{l}++ \\
5.22 \mid 0.75\end{array}$ \\
\hline ... trust in cooperation structures & $\begin{array}{l}++ \\
5.22 \mid\end{array} 0.66$ \\
\hline ... a common vision for $\mathrm{ABls}$ & $\begin{array}{l}++ \\
5.21 \mid 0.79\end{array}$ \\
\hline ... financial agency & $\begin{array}{l}++ \\
5.14 \mid 0.78\end{array}$ \\
\hline $\begin{array}{l}\text {... permanent structures of local } \\
\text { educational management }\end{array}$ & $\begin{array}{l}++ \\
5.07 \mid 0.80\end{array}$ \\
\hline ... a formal decision for $A B l s$ & $\begin{array}{l}++ \\
5.05 \mid 0.79\end{array}$ \\
\hline ... local power relations & $\begin{array}{l}++ \\
5.04 \mid 0.72\end{array}$ \\
\hline ... individual commitment & $\begin{array}{l}++ \\
4.93 \mid 0.75\end{array}$ \\
\hline$\ldots$ the distribution of responsibilities & $\begin{array}{l}++ \\
4.74 \mid 0.63\end{array}$ \\
\hline$\ldots$ the participation of ABI-users & $\begin{array}{l}++ \\
4.62 \mid 0.94\end{array}$ \\
\hline$\ldots$ the qualification of $\mathrm{ABI}$-professionals & $\begin{array}{l}++ \\
4.61 \mid 0.75\end{array}$ \\
\hline ... impulses from civil society & $\begin{array}{l}+ \\
4.22 \mid\end{array} 0.79$ \\
\hline
\end{tabular}


These estimations correspond with findings on the impact of broader social contexts, which shapes implementation and goes beyond the scope of ABIs (see above).

Regarding ABI structures, the data provides two differentiations (on the scope of ABIs). Firstly, cooperation among $\mathrm{ABI}$ professionals is considered more desirable and more likely than participation of ABI users. This finding is underscored by the fact that civil society is expected to be the lowest driver of ABI development and the statement "There will be models for participation, but decisions will continue to be made top-down" is rated as one of the most likely developments. These estimations correspond with ([37]: 127) statement that ABIs are not participatory concepts. Further, the prioritization of cooperation among actors over participation accords with findings that the most dynamic developments can primarily be found on the level of multi-professional cooperation. ABIs turned out to, above all, stimulate learning processes for multiprofessional competencies among local actors ([30]: 58; [33]: 248; [28]: 16). In view of the simplistic assumptions underlying the first generation of ABIs (see above), these are unintended secondary effects ([28]: 16; [59]: 218). Secondly, coordination is considered more desirable and more likely than replacing established structures within the German educational system, which was a crucial claim in the beginning of the debate. This corresponds with findings on the potential of ABIs. According to Manitius [30], it "keeps efforts for innovation within the network (dimension of stability) and reduces transaction costs for participants through management of knowledge, data and administrative issues" ([30]: 58-59). Monitoring of "Learning Locally" reveals that coordinators "allowed greater acceptance of cooperation through well-prepared meetings and active communication" ([33]: 255). Newer studies $[59,60]$ highlight the role of learning and active knowledge-management, and therefore, coordination. Interestingly, despite adjusted expectations, the remaining discrepancy between desirable and likely developments, and the limited scope on the structural level, experts still want and expect ABIs to be leading models for educational reform (see pp. \#\#). The fact that the concept is not directly valued in terms of achieving its initial goals shows how resilient desires are and points to the notion of rationalized myth. At the same time, this fact confirms the crucial role of expectations as drivers of $\mathrm{ABI}$ development. This corresponds to Nardi's [61] critique of studies of collaboration for their focus on how it is achieved, arguing that more attention needs to be given to why people engage in collaboration and what their "passionately held motives" are (ibid.: 37; see also [62]: 40).

Regarding future challenges and drivers, the role of expectations was neglected in the questionnaire, which reflects the assumptions of research and debate at the time it was created. The findings on future developments resemble challenges that emerged in the recent phase of transfer from the structure of a project to a regular program ([63]: 72-73), which focused on convincing decision-makers to provide long-term perspectives for ABI development. The professional's bottom-up activities require corresponding top-down structures [64]. Regarding decision-makers, adapted expectations prove to be a challenge: Politically, only user-level outcomes on seem to legitimately demonstrate the value of ABIs ([65]: 259). Further, the high standard deviation in responses on future challenges corresponds to the variety of conditions in practice: While some local decision-makers have other priorities entirely, others are explicitly interested in ABIs as a means to spur administrative change. This implies that different approaches are required in appealing to decision-makers to provide long-term perspectives.

\section{Conclusion}

The study focuses on the future development of German ABIs in the stage of transfer: Is the recent gap between intentions and implementation going to be resolved or remain as it is? Is development still based on the rationalized myths that cause this gap, or are these myths being replaced by valid knowledge from ten years of $A B I$ experiences? And what is crucial for purposeful ABI development?

This study shows that after one decade of experience, expectations for ABI development have been adjusted. Discrepancies between intentions and implementation are expected to remain in 2030. User-level ABI aims such as improved learning outcomes or reduced social disadvantage are still considered very desirable but less likely, and even if respondents want a broader understanding of education beyond school, they expect a continued focus on formal education. Further, in contrast to the ideal that ABIs are only legitimate if they a have positive impact on young people's lives and should not be reduced to networking for the sake of networking, the study reveals a focus on the structural level. Therefore, future development does indeed risk becoming mired in the governance trap and continuing to fail forward.

However, expectations correspond to research findings. The prioritizing of cooperation among local professionals over the participation of civil society accords with findings that ABIs above all achieve the secondary effect of stimulating learning about others' professions as a precondition for multi-professional cooperation. Further, the focus on coordination within established structures bears the potential to shape learning processes among ABI participants. Hence, after 10 years of experience, ABIs are no longer based on unrealistic expectations or rationalized myth but correspond to findings on their actual scope. According to general findings of $\mathrm{ABI}$ research, that is the precondition for 
reducing the discrepancy between intentions and implementation on a more realistic level.

At the same time, the study highlights the role of high expectations for the user level as drivers for future $A B I$ development. Expectations that lie beyond the scope of ABIs are crucial for ABI actors' motives for participation as well as for long-term perspectives being provided by local decision-makers. Hence, expectation management appears to be a crucial task of purposeful ABI development, and professional ABI coordination requires balancing feasible goals and high expectations. The fact that experts still strongly desire ABIs to be a successful approach to coping with educational challenges in 2030 creates the space for future developments based on valid knowledge. Finally, to create a long-term perspective, the study highlights the need to balance the expectations driving ABI development with ABIs' actual scope. Therefore, it might help to define the relations and contributions of actual achievements of interventions to aims on the user level. As ABIs are affected by many factors, their scope remains an open question. Yet, based on experience and valid knowledge and in view of the potential to share this knowledge through coordination, conditions for purposeful ABI development in Germany are better than ever.

\section{Abbreviation}

$A B \mid$ : Area-based initiative

\section{Acknowledgements}

Thanks to Stefanie Schmachtel, Martin-Luther-Universität Halle-Wittenberg, Nele Fischer, the journal's managing editor, and two anonymous reviewers for their valuable and constructive comments on prior versions of this paper.

\section{Authors' contributions}

$A D$ interpreted the data and was the major contributor in writing the manuscript. JG was responsible for all statistical analysis of data and supported writing. $\mathrm{GdH}$ is project leader. He initiated and funded the project. KW designed and conducted the study from 2016 to 2018. The author(s) read and approved the final manuscript.

\section{Funding}

The study is exclusively funded by means of the Institut Futur of the Freie Universität Berlin. Open Access funding enabled and organized by Projekt DEAL.

\section{Availability of data and materials}

The dataset used and analyzed during the current study are available from the corresponding author on reasonable request.

\section{Declarations}

Ethics approval and consent to participate Not applicable.

\section{Consent for publication}

Not applicable.

\section{Competing interests}

The authors declare no competing interests.
Received: 26 March 2020 Accepted: 29 March 2021

Published online: 15 May 2021

\section{References}

1. Hargreaves A, Shirley D (2009) The fourth way: the inspiring future for educational change. Corwin Press, Thousand Oaks

2. Poortman CL, Brown C (2018) The importance of professional learning networks. In: Brown C, Poortman CL (eds) Networks for learning. Effective collaboration for teacher, school and system improvement. Routledge Taylor \& Francis Group, London, New York

3. Binkley M, Erstad O, Herman J, Raizen S, Ripley M, Miller-Ricci M, Rumble M (2012) Defining twenty-first century skills. In: Griffin P, McGaw B, Care E (eds) Assessment and Teaching of 21st Century Skills, vol 32. Springer Netherlands, Dordrecht, pp 17-66. https://doi.org/10.1 007/978-94-007-2324-5 2

4. Pellegrino JW, Hilton ML (2012) Education for life and work. National Academies Press, Washington, D.C

5. OECD (2016) What makes a school a learning organisation?: a guide for policy makers, school leaders and teachers. https:/www.oecd.org/educa tion/school/school-learning-organisation.pdf. Accessed 3 Feb 2020

6. Kerr K, Dyson A (2017) Area-based responses to educational disadvantage. oxfordre.com/education

7. OECD (2001) Lernen für das Leben: Erste Ergebnisse der internationalen Schulleistungsstudie PISA 2000. http://www.oecd.org/education/school/ programmeforinternationalstudentassessmentpisa/33691612.pdf. Accessed 18 Jan 2021

8. Gottschall K (2001) Erziehung und Bildung im deutschen Sozialstaat. Stärken, Schwächen und Reformbedarfe im europäischen Vergleich. Bremen (ZeS-Arbeitspapier, 9). http://www.ssoar.info/ssoar/bitstream/handle/ document/ 11553/ssoar-2001-gottschall-erziehung_und_bildung_im_ deutschen.pdf?sequence=1, Accessed 14 Jan 2015

9. Heinrich AJ (2018) Die sozialräumliche Bildungslandschaft Campus Rütli in Berlin-Neukölln: Begründungen und Bedeutungen aus der Perspektive gestaltender Akteure, 1st. Edition 2018. Quartiersforschung. Springer Fachmedien Wiesbaden, Wiesbaden

10. Duveneck A (2016) Bildungslandschaften verstehen: Zum Einfluss von Wettbewerbsbedingungen auf die Praxis, 1st edn. Edition Soziale Arbeit. Beltz Juventa, Weinheim

11. Million A, Coelen T, Heinrich AJ, Loth C, Somborski I (2017) Gebaute Bildungslandschaften: Verflechtungen zwischen Pädagogik und Stadtplanung. jovis, Berlin

12. Maykus S (2017) Bildungslandschaften aus systemtheoretischer Sicht. In: Olk T, Schmachtel S (eds) Educational Governance in kommunalen Bildungslandschaften, 1st edn. Beltz Juventa, Weinheim, Basel, pp 127-147

13. Duveneck A, Volkholz S (2012) Kommunale Bildungslandschaften. Schriftenreihe zu Bildung und Kultur, vol 9. Heinrich-Böll-Stiftung, Berlin

14. BMBF - Bundesministerium für Bildung und Forschung (2009) Lernen vor Ort. https://www.transferinitiative.de/129.php

15. Brüggemann C, Tegge D (2018) Strukturen kommunalen Bildungsmanagements in Deutschland. Workingpaper. https://www.resea rchgate.net/publication/328364893_Bruggemann_Tegge_2018_Strukturen_ kommunalen_Bildungsmanagements_in_Deutschland

16. Schäfer K (2009) Herausforderungen bei der Gestaltung kommunaler Bildungslandschaften. In: Bleckmann P, Durdel A (eds) Lokale Bildungslandschaften: Perspektiven für Ganztagsschulen und Kommunen, 1st edn. VS Verl. für Sozialwiss, Wiesbaden, pp 233-249. https://doi.org/10.1 007/978-3-531-91857-0_17

17. Stolz H-J (2012) Jugendhilfe und Schule in der lokalen Bildungslandschaft. In: Markowetz R, Schwab JE (eds) Die Zusammenarbeit von Jugendhilfe und Schule. Inklusion und Chancengerechtigkeit zwischen Anspruch und Wirklichkeit. Julius Klinkhardt, Bad Heilbrunn, pp 90-113

18. Sass E (2015) Bildung(s)gestalten: Die Offene Kinder- und Jugendarbeit und die Familienbildung auf dem Weg zu Bildungslandschaften von unten. Bericht der wissenschaftlichen Begleitung des Projekts "Bildung(s)gestalten" - Offene Kinder- und Jugendarbeit und Familienbildung gestalten Bildungslandschaften, Dortmund. http://www. forschungsverbund.tu-dortmund.de/fileadmin/Files/Kinder-_und_Jugenda rbeit/Bildung_s_gestalten/Bildung_s_gestalten_Bericht_wiss.Begleitung. pdf. Accessed 23 June 2016

19. Schlingensiepen-Trint K (2019) Zwischen Freiraum und Steuerung handlungsfeldübergreifende Bildungslandschaften 
20. Bénabou R, Kramarz F, Prost C (2009) The French zones d'éducation prioritaire: Much ado about nothing? Econ Educ Rev 28(3):345-356. https:// doi.org/10.1016/j.econedurev.2008.04.005

21. Rochex J-Y (2012) Twenty-five years of priority education policy in France: dubious specificity and disappointing results. In: Demeuse M, Frandji D, Greger D, Rochex J-Y (eds) Educational Policies and Inequalities in Europe, vol 61. Palgrave Macmillan UK, London, pp 93-123. https://doi.org/10.1057/ 97802303586524

22. Cochrane A (2007) Understanding urban policy: a critical approach. Blackwell Publishing, Malden

23. Rees G, Power S, Taylor C (2007) The governance of educational inequalities: the limits of area-based initiatives. J Comp Policy Anal: Res Pract 9(3):261274. https://doi.org/10.1080/13876980701494665

24. Berkemeyer N, Bos W, Manitius V, Müthing K (2008) "Schulen im Team" Einblicke in netzwerkbasierte Unterrichtsentwicklung. In: Berkemeyer N (ed) Unterrichtsentwicklung in Netzwerken: Konzeptionen, Befunde. Perspektiven. Waxmann, Münster, pp 19-73

25. Jacobs Foundation (2016) So entstehen erfolgreiche Bildungslandschaften -- ein Zwischenbericht: Begleitstudie Bildungslandschaften Schweiz, Zürich

26. Lohre W (ed) (2008) Selbstständige Schulen in regionalen Bildungslandschaften: Eine Bilanz ; mit 19 Regionenporträts, 1st. Edition Beiträge zu "Selbständige Schule". Bildungsverl. EINS, Troisdorf

27. Schalkhaußer S, Thomas F (2011) Lokale Bildungslandschaften in Kooperation von Jugendhilfe und Schule, München

28. Schmachtel S, Olk T (2017) Educational governance in kommunalen Bildungslandschaften: Empirische Befunde und kritische Reflexionen eine Einführung. In: Olk T, Schmachtel S (eds) Educational Governance in kommunalen Bildungslandschaften. Juventa, Weinheim, Basel, pp 1051

29. Huber, SG (2014) Kooperation in Bildungslandschaften: Aktuelle Diskussionsstränge, Wirkungen und Gelingensbedingungen. Huber, SG (ed) (2014) Kooperative Bildungslandschaften. Netzwerke(n) im und mit System. Carl Link (Praxishilfen Schule), Köln, Kronach, pp. 3-29

30. Manitius V (2013) Regionalisierung und Gerechtigkeit?: Eine Betrachtung auf Chancen und Risiken entlang theoretischer und empirischer Hinweise. Dissertation. https://eldorado.tu-dortmund.de/bitstream/2003/31154/1/ dissertation.pdf. Accessed 16 Jan 2019

31. Arbeitsgruppe "Lernen vor Ort" (2016) Kommunales Bildungsmanagement als sozialer Prozess: Studien zu "Lernen vor Ort". Educational Governance, vol 33. Springer VS, Wiesbaden

32. Kappauf Z, Riek A, Kolleck N, G de Haan, Schuster J, Dabisch V (2016) RuhrFutur im Blick der Wissenschaft: Erkenntnisse und Empfehlungen aus der Begleitforschung einer Bildungslandschaft. IF Schriftreihe Sozialwissenschaftliche Zukunftsforschung. https://www.ewi-psy.fu-berlin.de/ einrichtungen/arbeitsbereiche/bildungsfor_modell_analyse_soz_systeme/ Forschung/RuhrFutur_Policy-Paper.pdf. Accessed 5 Feb 2019

33. Niedlich S, Klausing J, Rädler M (2016) Was bringt's, was bleibt?: Zu Wirkungen und Nachhaltigkeit datenbasierten kommunalen Bildungsmanagements. In: Arbeitsgruppe "Lernen vor Ort" (ed) Kommunales Bildungsmanagement als sozialer Prozess: Studien zu "Lernen vor Ort". Springer VS, Wiesbaden, pp 237262. https://doi.org/10.1007/978-3-658-12442-7_11

34. Niemann L (2014) Steuerung lokaler Bildungslandschaften: Räumliche und pädagogische Entwicklung am Beispiel des Projektes Altstadt Nord Köln. Zugl.: Dortmund, Techn. Univ., Diss., 2013. Springer VS, Wiesbaden

35. Rolff H-G (2013) Auswertung der Evaluation und Empfehlungen zur Weiterentwicklung der Regionalen Bildungsnetzwerke in NRW: Eine Expertise. https://www.brd.nrw.de/schule/pdf/RBNW-expertise-zur-evalua tion_13.pdf

36. Sass E (2017) Jugendverbandsarbeit im Bildungsnetz: "Wir hier Jugendverbände und Jugendringe in Kommunalen Bildungslandschaften" - ein Bericht der wissenschaftlichen Begleitung, Dortmund. http://www.forschungsverbund.tu-dortmund.de/fileadmin/ Files/Kinder__und_Jugendarbeit/Jugendverbandsarbeit_im_Bildungsnetz_ Sass.pdf. Accessed 6 Feb 2019

37. Stolz H-J (2010) Lokale Bildungslandschaften in Kooperation von Ganztagsschule und Jugendhilfe. Ausgewählte Ergebnisse. In: Nerowski C, Weier U (eds) Ganztagsschule organisieren - ganztags Unterricht gestalten Univ. of Bamberg Press, Bamberg, pp 121-134

38. Berse C (2009) Mehrdimensionale Bildung im Kontext kommunaler Bildungslandschaften: Bestandsaufnahme und Perspektiven. Univ., Philosophische Fakultät III, Diss.--Halle, 2009. Budrich UniPress, Opladen
39. Weiß WW (2011) Kommunale Bildungslandschaften: Chancen, Risiken und Perspektiven. Veröffentlichungen der Max-Traeger-Stiftung, vol 48. JuventaVerl, Weinheim

40. Olk T, Stimpel T (2011) Kommunale Bildungslandschaften und Educational Governance vor Ort. Bildungspolitische Reformpotenziale durch Kooperation und Vernetzung formeller und informeller Lernorte? In: Bollweg P, Otto HU (eds) Räume flexibler Bildung. Bildungslandschaft in der Diskussion. VS Verlag, Wiesbaden, pp 137-155

41. Bleckmann P, Durdel A (2009a) Lokale Bildungslandschaften: Perspektiven für Ganztagsschulen und Kommunen, 1. Edition VS Verlag für Sozialwissenschaften / Springer Fachmedien Wiesbaden GmbH Wiesbaden, Wiesbaden. https://doi.org/10.1007/978-3-531-91857-0

42. Bleckmann P, Durdel A (2009b) Resümee: Vom gesellschaftlichen Wert zielgerichteten Netzwerkens. In: Bleckmann P, Durdel A (eds) Lokale Bildungslandschaften: Perspektiven für Ganztagsschulen und Kommunen, 1st edn. VS Verl. für Sozialwiss, Wiesbaden, pp 285-292. https://doi.org/10.1 007/978-3-531-91857-0_20

43. Grande E (2012) Governance-Forschung in Der Governance-Falle? - Eine Kritische Bestandsaufnahme. Politische Vierteljahresschrift 53(4):565-592. https://doi.org/10.5771/0032-3470-2012-4-565

44. Babidge S, Belfrage M (2017) Failing forward: a case study in neoliberalism and abandonment in Calama. Cult Dyn 29(4):235-254. https://doi.org/10.11 77/0921374017743300

45. Dirks S, Kessl F, Lippelt M, Wienand C (2016) Urbane Raum(re)produktion Soziale Arbeit macht Stadt. In: Raumproduktionen, Band 20, 1st edn. Westfälisches Dampfboot, Münster

46. Schmachtel S (2015) Local partnerships as 'rationalized myths': a critical examination of the micro-discourse in educational partnership working. Crit Policy Stud 10(4):448-467. https://doi.org/10.1080/19460171.2015.1077719

47. Emmerich M (2017) Semantiken regionaler Bildungssteuerung. In: Olk T, Schmachtel S (eds) Educational Governance in kommunalen Bildungslandschaften, 1st edn. Beltz Juventa, Weinheim, Basel, pp 78-99

48. Mayer JW, Rowan B (1977) Institutionalized organizations: formal structure as myth and ceremony. Am J Sociol 83(2):340-363. https://doi.org/10.1 $086 / 226550$

49. Stolz H-J, Schalkhaußer S, Täubig V (2011) "Vernetzte Bildung" - Ein institutioneller Mythos? In: Bollweg P, Otto H-U (eds) Räume flexibler Bildung: Bildungslandschaft in der Diskussion, 1st edn. VS-Verl, Wiesbaden, pp 67-79

50. Schmachtel S (2019) Die Sache mit den 'Mythen' bezüglich des weiten Bildungsbegriffs. http://www.neuordnungen.he-hosting.de/2019/04/29/stefa nies-input/

51. Brüggemann C (forthcoming) Datenbasiertes Bildungsmanagement als Steuerungsversprechen der Regionalisierungspolitik im Bildungswesen. Zeitschrift für Pädagogik 67(3)

52. Otto J, Manitius V (2017) Die Kooperationsidee von Bildungslandschaften eine kritische Würdigung. In: Olk T, Schmachtel S (eds) Educational Governance in kommunalen Bildungslandschaften, 1st edn. Beltz Juventa, Weinheim, Basel, pp 204-227

53. Häder M (2009) Delphi-Befragungen: Ein Arbeitsbuch, 2nd edn. VS Verl. für Sozialwiss, Wiesbaden. https://doi.org/10.1007/978-3-531-91926-3

54. Mayring P (2002) Qualitative Sozialforschung: Eine Anleitung zu qualitativem Denken, 5., überarb. und neu ausgestattete Edition Beltz-Studium. Beltz Verlagsgruppe, [Weinheim]

55. Meuser M, Nagel U (2009) Das Experteninterview — konzeptionelle Grundlagen und methodische Anlage. In: Pickel S, Pickel G, Lauth $\mathrm{H}-J$, Jahn D (eds) Methoden der vergleichenden Politik- und Sozialwissenschaft. VS Verlag für Sozialwissenschaften, Wiesbaden, pp 465-479. https://doi.org/10.1 007/978-3-531-91826-6_23

56. Moher D, Hopewell S, Schulz KF, Montori V, Gøtzsche PC, Devereaux PJ, Elbourne D, Egger M, Altman DG (2010) CONSORT 2010 explanation and elaboration: updated guidelines for reporting parallel group randomised trials. J Clin Epidemiol 63:e1-37. https://doi.org/10.1016/j. jclinepi.2010.03.004, 8

57. Fritz CO, Morris PE, Richler JJ (2012) Effect size estimates: current use, calculations, and interpretation. J Exp Psychol Gen 141(1):2-18. https://doi. org/10.1037/a0024338

58. Cohen J (1992) A power primer. Psychol Bull 112(1):155-159. https://doi org/10.1037/0033-2909.112.1.155

59. Niedlich S (2020) Neue Ordnung der Bildung. Zur Steuerungslogik der Regionalisierung im deutschen Bildungssystem. Springer VS, Wiesbaden. https://doi.org/10.1007/978-3-658-27206-7 
60. Sendzik N (2020) Zwischen Wandel und Stabilität. Die Rolle von Regionalen Bildungsbüros beim Abbau von Bildungsungleichheit. ZBW - Leibniz Information Kiel, Hamburg

61. Nardi B (2005) Objects of desire: power and passion in collaborative activity Mind Cult Act 12(1):37-51. https://doi.org/10.1207/s15327884mca1201_4

62. Edwards A (2009) Relational agency in collaborations for the well-being of children and young people. J Child Serv 4(1):33-43. https://doi.org/10.11 08/17466660200900004

63. Brüsemeister $\mathrm{T}$ (2017) Educational governance in kommunalen Bildungslandschaften - Zur Literalität von Kommunen im Programm "Lernen vor Ort". In: Olk T, Schmachtel S (eds) Educational Governance in kommunalen Bildungslandschaften, 1st edn. Beltz Juventa, Weinheim, Basel, pp 52-77

64. Nast J (2018) Top-down und bottom-up: Bildungsverbünde im bezirklichen Bildungsmanagement gestalten, Bildungsnetzwerke und Bildungsverbünde Gestern - Heute - Morgen. Dokumentation der Fachtagung vom 27. November 2017 in der Alten Feuerwache, Berlin-Kreuzberg.

65. Brüsemeister T (2016) Educational governance in kommunalen Bildungslandschaften. In: Arbeitsgruppe "Lernen vor Ort" (ed) Kommunales Bildungsmanagement als Sozialer Prozess. Studien zu Lernen vor Ort. Educational Governance, vol 33. Wiesbaden, Springer VS, pp 211-236. https://doi.org/10.1007/978-3-658-12442-7_10

\section{Publisher's Note}

Springer Nature remains neutral with regard to jurisdictional claims in published maps and institutional affiliations.

\section{Submit your manuscript to a SpringerOpen ${ }^{\circ}$ journal and benefit from:}

- Convenient online submission

- Rigorous peer review

- Open access: articles freely available online

High visibility within the field

- Retaining the copyright to your article

Submit your next manuscript at $\boldsymbol{\nabla}$ springeropen.com 